\title{
American Studies in Belarus
}

\section{(2) OpenEdition}

\section{Journals}

Édition électronique

URL : https://journals.openedition.org/ejas/430

DOI : $10.4000 /$ ejas.430

ISSN : 1991-9336

Éditeur

European Association for American Studies

Référence électronique

Yuri Stulov, «American Studies in Belarus », European journal of American studies [En ligne], 1-1 | 2006, document 3, mis en ligne le 13 janvier 2006, consulté le 09 juillet 2021. URL : http://

journals.openedition.org/ejas/430; DOI : https://doi.org/10.4000/ejas.430

Ce document a été généré automatiquement le 9 juillet 2021.

Creative Commons License 


\section{American Studies in Belarus}

1 The interaction of cultures is becoming an ever growing factor in the world of today. 1989 was the year that promised tremendous changes in the relations between countries and nations. The barriers that had separated people in the East and in the West were smashed, and it seemed that the future was going to be a straight thoroughfare leading to mutual understanding and prosperity. People on both sides of the Berlin Wall suddenly realized how many things they had to share and how much they could learn from each other. This incited enormous interest in the cultural heritage of other countries, especially in the former communist bloc.

2 The collapse of the Soviet Union resulted in the emergence of 15 independent states, some of which are still in the process of self-identification. They are called upon to reevaluate their position in the world and their role in world civilization.

3 The history of Belarus is quite dramatic. Throughout its history the country had been continuously part of other states. The fact greatly affected Belarusian culture, which was marginalized by the culture of the dominant state but developed unique qualities that are determined by its position at the cross-roads of cultures. The country gave the world Marc Chagall and M.Bogdanovich, but has difficulty with self-identification.

Belarus had always had a special relationship with the United States of America. Tadeusz Kosciuszko, the great hero of the American Revolution, was born in Belarus. Marc Chagall whose frescoes decorate the United Nations building in New York comes from the Belarusian city of Vitebsk. Among the Nobel Prize winners who made their career in the U.S.A. are a few Belarusian-born academics. A number of American writers have their ethnic roots in Belarus. On the other hand, the Belarusian Diaspora in the U.S.A. has never got much publicity. At the beginning of the $20^{\text {th }}$ century, thousands of Belarusians moved to the U.S.A. in search of the Promised Land. The majority of those emigrants were illiterate people who came from small poor villages. It is quite remarkable that far away from their homeland they had preserved the language and authentic Belarusian culture, which were vanishing in Belarus because of the attempts at russification and the extermination of the nation's elite in GULAG.

5 However, in spite of these cross-cultural links, the study of America in Belarus has been inadequate and fragmented. The first translations of books by Mark Twain, Erskine Caldwell, Jack London and other major American authors into Belarusian appeared 
during the Belarusian Revival of the 1930s, and the first Ph. D. dissertations dealing with the U.S.A. date back to the post-WW II period.

6 New opportunities for the study of America appeared after 1991 with the development of academic exchanges and cooperation between the two countries.

7 American Studies are among the very new things that have appeared on the university syllabus over the last fifteen years, though traditionally they involve philology students. It will be wrong to say that there has been no expertise in the field of American Studies, but to this day American Studies have not been institutionalized (with the exception of the American Studies Center at the European Humanities University, which, regretfully, was closed in 2004.) However, the EHU ASC has managed to train a number of teachers and researchers who have elaborated a number of American Studies courses that are being introduced at different universities. Textbooks have been made, distance courses developed. The next step is to make American Studies interdisciplinary.

8 One of the most important fields of American Studies is American Literature. The study of American Literature in Russia (Belarus then was part of the Russian Empire) started as far back as the second quarter of the nineteenth century. Washington Irving, James Fenimore Cooper and Edgar Allan Poe were as popular in Russia as they were in the U.S.A. However, during the communist regime years our knowledge of American literature was specific. On the one hand, the names of U.S. great classics were well-known to every educated person, and some of the literary characters, like Huck Finn or Tom Sawyer, were immediately identified not only as phenomena of American culture but also as part of the local cultural tradition. On the other hand, there were noticeable lacunae in the study of even the greatest of American authors. Usually the critics emphasized the social criticism their books contained but were suspicious about the experiments with form which are characteristic of American authors. Jack London was acknowledged as the most popular American writer (the number of his books published in the USSR exceeded that of any other foreign author) while Henry James began to be carefully studied only quite recently. This overemphasis on Jack London is easy to explain: he was one of V. Lenin's favourite authors, and his story "Love of Life" was mentioned by N. Krupskaya as the one she used to read to the dying Lenin during his last days. It is only now that Jack London is being adequately evaluated-in the complexity of his strengths and weaknesses.

9 Such discrepancies are typical of the whole course of the history of American Literature which was taught in this part of the world. Some of the literary figures were blown out of all proportion because of their ideological message ; others were underestimated in spite of their tremendous contribution to world literature. The reading lists for university students included mainstream writers like Ernest Hemingway, Francis Scott Fitzgerald, William Faulkner along with people like John Reed or A. R. Williams who were journalists and not really important literary figures. Modern American Literature was not adequately represented, the giants of the 1930s-40s being the most recent.

Another peculiar feature of the study of American Literature was that it focused almost exclusively on the mainstream with little concern for minority literatures or for what is regarded as low or popular culture. It is only during the last decade or so that Belarusian Americanists have started to analyze the trends that determine the American literary scene today, taking special notice of the effects of multiculturalism. The result is the book market that is beginning to demonstrate a change in the readers' attitudes, making the map of American Literature more complete. 
11 The Belarusian Association for American Studies was established in 1995. Its history is both dramatic and exciting. It unites Americanists not only from Belarus but also from the neighboring countries, such as Ukraine and Lithuania. Their major forum is the annual conference that has been held since 1991, and the American Studies Yearbook (published since 1995) has become a recognized source of information about American Studies in Eastern Europe. It is clear that the questions Belarusian Americanists are called upon to solve are more numerous than the answers they can give at the moment. It also explains the need for the new generation of specialists in American Studies who will be able to do what their predecessors could not, for various reasons.

12 And this is a great challenge, isn't it? 